Reports of allergic reactions to penicillin are not numerous. W. Mitchie and H. W. C. Bailey (Brit. Med. J., 554, April 21, 1945) point out that they are much less numerous than allergic reactions to the sulphonamides. These authors record one case of sensitivity which was confirmed by application of penicillin to the undamaged skin of the arms, with the production five hours later of a kind of weeping eczema similar to that which had appeared on the wounded leg of this subject after treatment of the wound with penicillin dressings.

For the treatment of septic burns penicillin cream is regarded by the Medical Research Council's Burns Unit working at Glasgow (Med. Res. Council Special Report Series, No. 249. "Studies of Burns and Scalds." H.M. Stationery Office, 1944. 4s. net) as being the most certain method of eliminating hamolytic streptococci and staphylococci. Propamidine creams were also very good but were not so effective as the penicillin creams, of which the formulæ are given. After application of a cream containing about 120 units of either sodium or calcium penicillin per gram of eream, hamolytic streptococci disappeared from 41 out of 54 burns and did not reappear. One advantage of penicillin creams as compared with sulphonamide creams is that the serious risk of absorption of too large a dose of sulphonamide from the raw burned area is eliminated. Penicillin creams may, however, become infected by airborne organisms, such as Pseudomonas pyocyanea, which produces a penicillinase which decomposes penicillin. Prof. H. Berry (Lancet, 410, March 31, 1945) suggests that this difficulty may be overcome by the addition of 2 per cent of phenoxetol to the cream. Phenoxetol (see Nature, 154, 631, Nov. 18, 1944) attacks especially some of the Gram-negative and penicillinase-producing organisms which are not affected by penicillin, so that such a cream would not only help to preserve the potency of the penicillin cream but would also enhance its value by attacking organisms in it not sensitive to penicillin.

The administration of penicillin by inhalation of it in the form of an aerosol is described by N. Mutch and R. C. Rewell (Lancet, 650, May 26; 1945) and by F. A. Knott and W. H. Clark (Lancet, 468, April 14, $1945)$; R. B. Colos, A. N. Barker and E. A. Robertson (Lancet, 720, June 9, 1945) describe their use of penagar, which is 0.5 per cent watery agar containing the required dose of penicillin. It is not sticky, it retains its potency for a month in a refrigerator and can be put up in sterile bottles and collapsible tubes. Penicillin readily diffuses through the agar. The authors quote work which indicates that penicillin given in oils, creams and ointments is released too slowly and its diffusion is not good.

The use of penicillin for gas gangrene has been already noted (Nature, 155, 341, March 17, 1945; and 154, 677, Nov. 25, 1944). G. H. Fisher, M. E. Florey et al. (Lancet, 395, March 31, 1945) discuss in an important paper its use against clostridial infections. They argue that penicillin should be given for the prevention of gas gangrene rather than for its treatment when it is established, and record evidence which indicates that an inadequate prophylactic dose of penicillin may cause a serious clinical picture very different from that of gas gangrene or anærobic cellulitis. After a short interrupted course of penicillin, a profound and protracted toxæmia may result and the diagnosis of gas gangrene may be missed; so that the patient fails to get either gas gangrene antitoxin or further doses of penicillin. The local application of penicillin provided protection until surgical treatment was possible. C. Grimshaw and L. Stent (Lancet, 434, April 17, 1945) report on the successful treatment with penicillin of one case of post-operative eutaneous gangrene.

The use of penicillin for the purpose of obtaining bacteria-free cultures of protozoa has been known since 1944. A. H. Mahmoud (Ann. Trop. Med. Hyg., 38,219 ; 1944) successfully used penicillin to eliminate bacteria from cultures of Trichonionas foetus of cattle. Penicillin added to Kerr's medium for the cultivation of this protozoan to give a final dilution of 30 units per c.c. eliminated streptococci and staphylococci, but did not remove Proteus pseudovulgaris. Tr. fœetus grew in the absence of bacteria, and cultures of it were maintained. Penicillin has also been used by S. Adler and R. J. V. Pulvertaft (Ann. Trop. Med. and Hyg., 38, 188 ; 1944) to obtain bacteria-free cultures of Trichomonas vaginalis of man. Sterile cultures of Trichomonas hominis can be obtained by the method of S. Adler (Trans. Roy. Soc. Trop. Med. and Hyg., 35, 219; 1942), by which this organism is first grown on media containing prontosil rubrum and then injected with prontosil into the peritoneum of mice; whereupon the mice get rid of the remaining bacteria and the Trichomonas can then be grown on sterile media. But the method is not applicable to Trichomonas vaginalis, because this species does not survive in the mice for longer than twenty-four hours. The use of penicillin removes this difficulty and makes bacteria. free cultures possible.

G. LAPAge.

\section{PLANT STUDIES IN SYRIA}

$I^{N}$ the seientific world, Syria is gaining prominence chiefly with several important botanical studies made by the botanists of the Hebrew University at Jerusalem, where a representative Syrian collection has been compiled in the Herbarium, and by several expeditions of naturalists in the British Army who have collected specimens of fauna and flora for the British Museum under an Army organization known as the Middle East Biological Scheme. There are four great deserts in the Middle or Near East-Sinai, Negeb (Palestine), Judea and the adjacent Ghor (the 'Avrah), southern Iraq and the Syrian desert (which includes part of Transjordania)-available for investigation.

In the course of recent floristic studies in Syria and Palestine, several stations of an interesting tree, Pistacia atlantica, Desf., previously unknown in Asia, have been discovered (Zohary, Palestine J. Bot., Rehovat Series, 3; May 1940). This is one of the most important North African trees. Thousands of the trees were found by Prof. Zohary covering mountain-sides in northern Syria, and desert specimens were well developed. The tree was formerly more abundant, and is limited to more or less mild Irano-Turanian conditions, at altitudes from $-30 \mathrm{~m}$. to $+1,400 \mathrm{~m}$. Its discovery in a steppe region not suitable for irrigation culture of other plants has given rise to economic interest.

Prof. Zohary has also identified the "Ghada" tree of travel literature from the north Arabian and south Syrian deserts as Haloxylon persicum Bge. (Palestine $J$. Bot., Jerusalem Series, $1 ;$ 1940). This tree, which is of economic value for fuel, is of considerable phytogeographical interest, for its discovery in these 


\section{No. 3956 August 25, $1945 \quad$ N A T U R E}

deserts suggests affinities of these deserts with those of Central Asia. It is the only tree dominant for thousands of square miles which does not normally receive more than $25 \mathrm{~mm}$. of rainfall annually and is entirely destitute of aboreal plant communities away from wadis, except for Haloxylonetum persici; the discovery of this tree also suggests possibilities of economic development of the sterile deserts for fuel, charcoal, food for desert livestock and checking sand movements.

Considerable knowledge of the flora of the Syrian desert in general is being accumulated in the Depart ment of Botany of the Hebrew University, where a mass of new material awaits publication and adds considerably to the information in Dinsmore's 1932 edition of Post's classic "Flora of Syria, Palestine and Sinai", which the American University of Beirut published. Prof. Zohary has carried on the field studies of the late Prof. Eig and notable publications have been his "Geobotanical Analysis of the Syrian Desert" (Palestine J. Bot., Jerusalem Series, 2 ; 1940) and "To the Knowledge of the Flora of the Syrian Desert" (1; 1939) which covers the flora of the central part of the desert, with a rainfall of 95-210 mm. annually, and where 175 species were collected, 75 per cent of which were annuals, sometimes exclusively predominating over immense stretches. Some three hundred new species have been added to the flora of Iraq, of which about two hundred are new to science. The Syrian desert flora has been divided into three territories : Mediterranean, IranoTuranian (the most important) and Saharo-Sindian with 520, 588 and 239 species respectively; also there are 24 Sudano-Deccanian species, 10 EuroSibero-Boreoamerican, and 659 species belonging to two or more groups. Prof. Zohary's paper was the first to treat the vegetative character of the country.

\section{MASS MOVEMENT OF THE WATER SHREW, NEOMYS FODIENS}

$\mathrm{TN}$ the Journal of the Society for Preservation of the I Fauna of the Empire of June 1945 is a remarkable account by Lady Seton (a keen field naturalist and wife of that well-known observer the late Sir Malcolm Seton) of a movement of the water shrew, Neomys fodiens. In it she tells how she saw large numbers of this little mammal swimming up a small stream in Upper Teesdale in what appeared to be a mass migration. Migration is so exceptional among land mammals, if not marine ones (unlike birds in which it is so usual we may say it is the rule rather than the exception), that any instance is of outstanding interest.

Such mammalian migration as occurs is of two types: seasonal on the lines of bird migration, the North American caribou being the classic example, and occasional as in the case of the lemming, Lemmus lemmus, with its periodic emigrations from the high fields to the low country. These are seemingly initiated by pressure of numbers and scarcity of food, and the travellers appear to be driven by an urge to go downhill. I have watched the little animals scuttling along, each taking its own course and acting independently of fellow lemmings. I have never seen them moving in droves.

The especially interesting part of Lady Seton's account of the shrews she watched is the mass of animals. This is the more noteworthy for the fact that though Neomys fodiens is widely distributed throughout the mainland of Britain, it is usually only met with in sparse numbers. The only reference to water shrews in any number I can find is in Barrett-Hamilton's "History of British Mammals", wherein he refers to them living in family parties, and adds, "Probably, also, the breeding season brings these shrews together in companies, which would account for the party of nine or ten encountered by the late Canon H. B. Tristram on May 6, as well as for a concourse of twenty or thirty observed in Yorkshire by Mr. W. B. Arundel on the loth of the same month". But these are not described as being on the move. Migration does not appear to have been noted by previous observers in this or allied species. Thirdly, Lady Seton's water shrews were swimming upstream and therefore uphill, though why and where to we have no clue. Frances Pitr.

\section{SERUM PROTEINS IN THE ULTRACENTRIFUGE}

$T$ HE monograph on the proteins of blood serum by Kai O. Pedersen*, from Prof. Svedberg's laboratory at Uppsala, brings home forcibly the present complexity of the subject. Although any one of the usual methods of analysis gives apparently clear-cut fractions, each fraction when analysed by some other method usually turns out to be a mixture. The obvious remedy, to fractionate by each method in turn, is impracticable because some of the analytical methods are difficult to use in a preparative way. After a heroic attempt to achieve a complete separation, chiefly by means of ammonium sulphate with ultracentrifugal analysis, Dr. Pedersen had to confess defeat.

But a wealth of new knowledge has been gained, such as Dr. Pedersen's discovery of the new lowmolecular globulin 'fetuin', which was described in Nature of November 4, 1944. This is present in foetal serum of ruminants to the almost complete exclusion of the ordinary globulins and antibodies, which only appear after the animal has received colostrum. The same is true to a less marked extent in rodents and man. The discovery of fetuin is due to the ultracentrifuge, because in salting-out and in electrophoresis it behaves like ordinary $\alpha$-globulin. A foetal hæmoglobin has been known for some time; but a fotal serum globulin was unsuspected.

Dr. Pedersen's study of the ' $\mathrm{X}$-protein' is also illuminating. It has long been known that in undiluted serum some of the globulin sediments at the slow rate characteristic of albumin. This is surprising because a complex of the two proteins would normally sediment more rapidly than either component. Dr. Pedersen's explanation is that there is indeed a complex, but that it contains lipide, which decreases its density and therefore its sedimentation rate. The density is so low in human serum that with added salt the complex sediments upwards and can be isolated. This 'density-effect' cannot be observed in other sera, and similar interactions between apparently lipide-free proteins remain unexplained, so that the story still seems incomplete. 'X-protein' seems to be of physiological importance for lipide transport. J. St. L. Рншцот.

* Ultracentrifugal iStudies on Serum and Serum Fractions. By Kai O. Pedersen. Pp. 178. (Uppsala: Almqvist and Wiksells Boktryckeri AB, 1945.) 10 Swedish crowns. 